\title{
"Study on Customer satisfaction Index of various nationalized banks in comparison with private banks"
}

\author{
Smt. Savita S. Patil, Dr. Rajashekhar M. Patil \\ Research Scholar,PRIST UNIVERSITY, Thanjavur \\ Associate Professor, G.P.Porwal College, Sindgi.Karnataka
}

\begin{abstract}
Increased competition, highly educated consumers, and increase in standard of living are forcing many businesses to review their customer service strategy. Many business firms are channeling more efforts to retain existing customers rather than to acquire new ones since the cost of acquiring new customer is greater than cost of retaining existing customers. This Paper focuses on customer satisfaction of various nationalized banks in comparison with Private Banks. A survey was conducted for 600 respondents, 300 respondents who were customers of Private Banks and 300 respondents were customers of nationalized banks.
\end{abstract}

Keywords: Service Strategy, Business firms \& customers satisfaction.

\section{INTRODUCTION}

Bank plays a vital role in the economic development of a nation. It is a financial organization that accepts deposits and channels those deposits into loaning activities either directly or through capital markets. A bank connects customers that have capital deficits to those customers with capital surpluses. The banking industry in India isfacing boundchallengesi.e.challengesofqualityservice, client satisfaction, client retention, clie nt loyalty, Quality service plays a serious role in achieving client satisfaction, and making complete loyalty in banking sector.Effective service is one which would be distinguishing and understanding the wants of the individual client from time to time. Client service could be a dynamic interactive method that wants continuous improvement. With the advancement of data technology and communication system, the entire world has been reduced to a worldwide village. The customers at this juncture are well exposed to dynamic innovations in communication technology. He/she is attentive to the type of service level accessible round the world and so expects the simplest from his/her bank.In the last 20 years, regulatory, structural and technological factors have considerably modified the banking setting in Asian country. In an exceedingly surroundings that becomes progressively competitive, service quality as a crucial live of structure performance continues to compel the eye of banking establishments.

The interest is basically driven by the belief that higher service quality leads to customers' satisfaction and loyalty, larger disposition to suggest to some other person, reduction in complaints and improved client retention rates.Underneath these circumstances, the banks can have to be compelled to face prolonged challenges to retain the present customers and to make new customers. However, success rate depends on the innovative ways adopted by the banks together with higher client services and adequate fulfilment of client expectations.

\section{IMPORTANCE OF CUSTOMER SATISFACTION:}

Each bank has a unique kind of services as a result of this differentiation, services during this trade couldn't be standardized, what is more these services area unit intangible in nature that couldn't be compared or seen.Additional satisfaction of client depends upon service quality and repair quality is progressively offered as a method by marketers to position themselves more effectively within the market place. As a result of the arrival of e-banking, quality of service has been improved plenty as compared to ancient banking services. Net banking, Mobile banking, automated teller machine electronic fund transfer has wholly modified the manner of providing services by the banks.As customers become more sophisticated, therefore, it becomes essential to consider the use of technology to respond to their continuous needs. Banking is an industry highly involved with the customers. Customers in developing economies seems to keep the "technological factors" of services as the yardstick in differentiating good \& bad services and the human factor - the employees seem to play a lesser role in discriminating the quality of service for banks. The variations in services offered by the banks develop excellence for service quality. Banking is no longer regarded as 
business dealing with money transaction alone, but it also seem as a business related to information on financial transaction. Customers at the corporate level or at retail level have always been important for the banks. As electronic banking is becoming more prevalent, level of customer satisfaction is also changing the scenario of technological environment.Informational technology in the form of e-banking plays a significant role in providing better services at lower cost. Several innovative IT based services such as Automated Teller Machine (ATM), Internet banking, Smart Cards, Credit Cards, Mobile banking, Phone banking, Anywhere-Anytime banking have provided number of convenient services to the customer.So as the service quality improves, the probability of customer satisfaction increases. Increase satisfaction in turn increases the mutual understanding, customer retention and a bond of trust between customers and banks. The banks which are providing these services on a wider scale to customers are more reputed in the eyes of customers. But at the same time technology based product is different in public and private sector banks. Bank automation and electronic banking is fast in private sector comparative to public sector.banking is an improvement over traditional banking system because it has reduced the cost of transaction processing, improved the payment efficiency, financial services and also has improved the banker-customer relationship. The relationship between e-banking and service quality can be studied with the level of satisfaction. E-banking plays a pivotal role in giving satisfaction to the customers because e-banking fills the gap between the expected and perceived service quality. So in order to fill this gap, banks should find ways of making electronic services more accessible and by allowing the customer to verify the accuracy of the e-banking transactions. There are number of reasons due to which customer satisfaction on account ofe-banking hasimproved. The reasons are as follows;

1. Customer can withdraw funds, transfer funds anytime, anywhere they want.

2. Accessibility has been extended through technological development as it allows customers to do business from their home and office.

3. It makes the banking activities and transaction very simpler to understand

4. There is no requirement of direct control with bank, as services can be operated wherever customer wants.

5. It has reduced the waiting time of the customer;

6. Availability of employees at all times is notrequired as these services are provided 24 hours a day, seven days a week.

7. Internet based services has enabled the corporate and retail customers to transact from home, office and travelling.

8. Online fund transfer has enabled the customer to transfer funds from one bank to another or within the same bank at same time.

9. Communication, interaction between the bank andcustomerhasbeenimprovedduetoe-banking.

\section{Data Collection \& Analysis}

A) Selection of organisation

Three Private \& Three Nationalised Banks were considered for the study. Geographical area comprising of Bijapur, Bagalkot \& Belgaum Districts of Karnataka were considered for the study .

B) Sampling population

A total of Six Hundred Respondents were questioned with help of questionnaire.

C) Data collection

Data was collected with help of questionnaire, there was a primary survey and a secondary survey done .Results was then run through SPSS Software for analysis.

\section{RESULTS:}

Cronbach's alpha is a measure of internal consistency, that is, how closely related a set of items are as a group. It is considered to be a measure of scale reliability. A "high" value for alpha does not imply that the measure is one-dimensional.

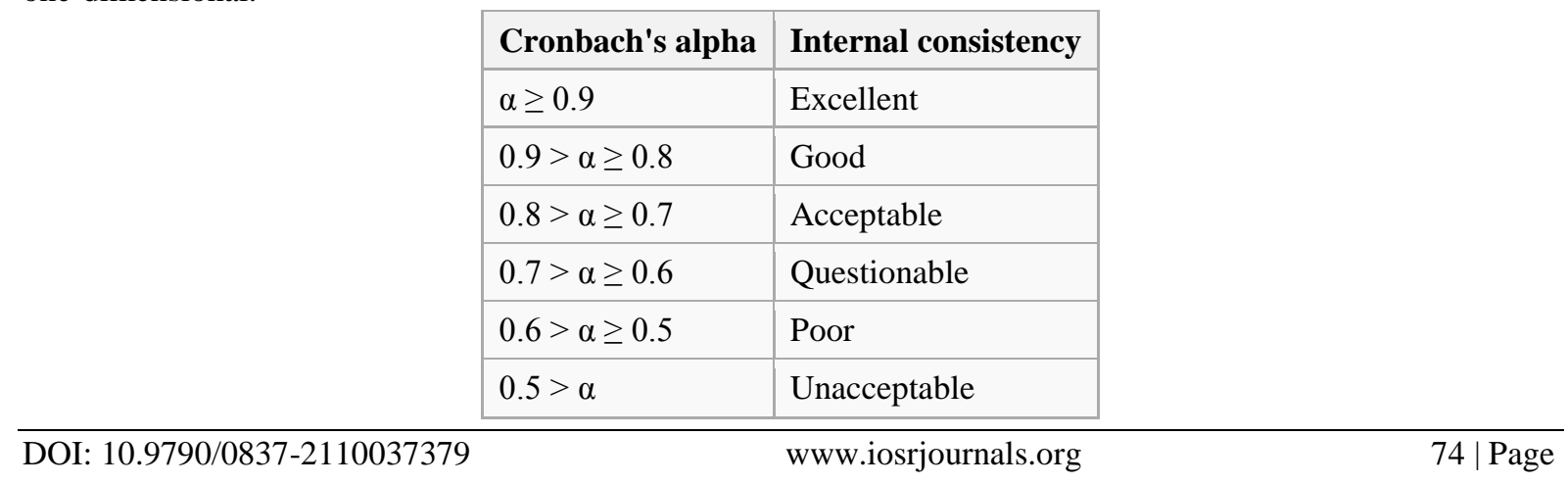


The reliability of questionnaire was 0.84 , which means our Questionnaire is good and acceptable.

Table 1: Frequency Distribution of respondents with respect to skills required in Private \& Nationalized Banks

\begin{tabular}{|c|c|c|c|c|c|}
\hline \multirow{3}{*}{$\begin{array}{c}\text { Private } \\
\text { Banks }\end{array}$} & \multicolumn{5}{|c|}{ The staff of the Bank has the skills required and knowledge about the } \\
services and products offered?
\end{tabular}

\begin{tabular}{|c|c|c|c|c|c|}
\hline \multirow{2}{*}{$\begin{array}{c}\text { Nationalized } \\
\text { Banks }\end{array}$} & \multicolumn{5}{|c|}{ The staff of the Bank has the skills required and knowledge about the } \\
services and products offered?
\end{tabular}

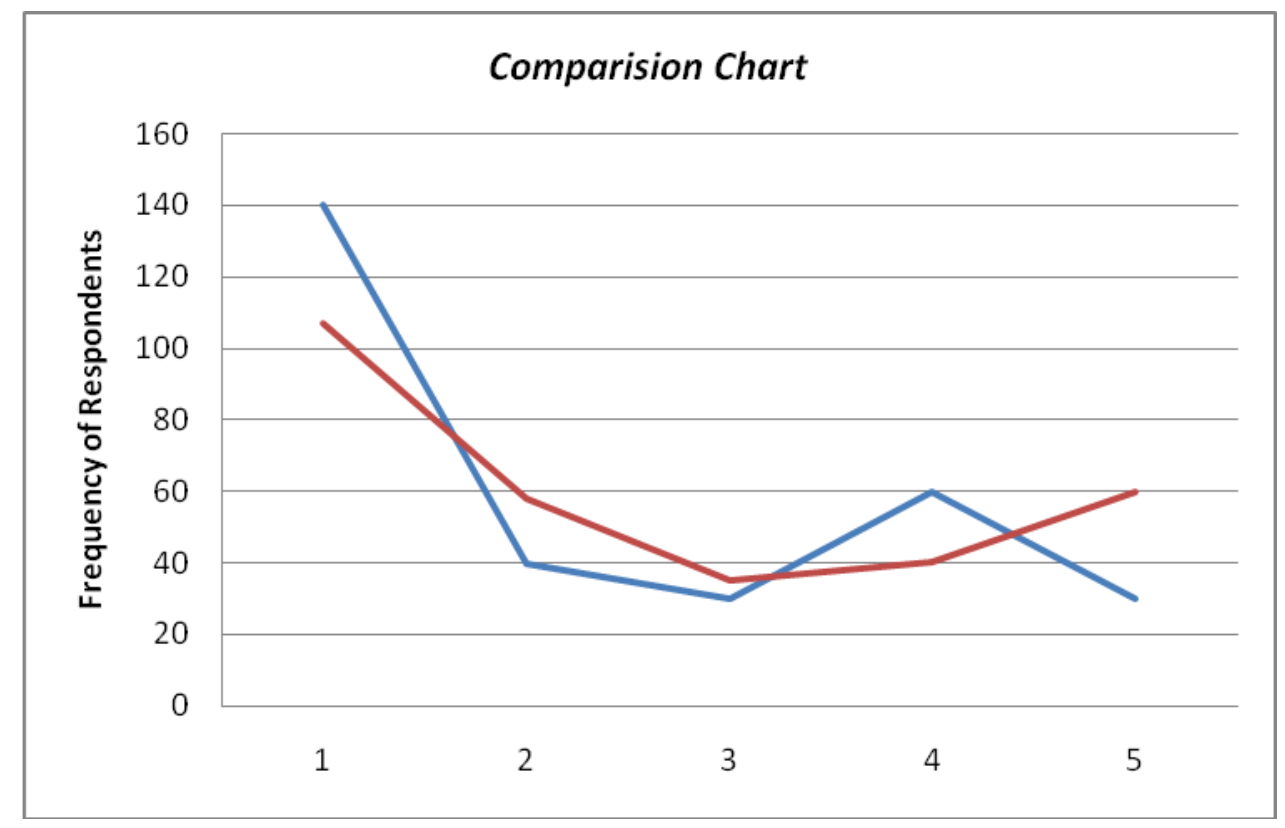

Figure 1: Comparison Line Graph for Frequency Distribution of respondents with respect to skills required in Private \& Nationalized Banks

It can be observed from the above graph and table that for the question posed to respondents regarding 'The staff of the Bank has the skills required and knowledge about the services and products offered?', The respondents of Private Banks answered as follows - $46 \%$ of respondents strongly agreed, $13.33 \%$ of respondents agreed, 10.5 of respondents didn't hold any opinion, whereas $20 \%$ of respondents disagreed and $10 \%$ of respondents strongly disagreed. The respondents of Nationalized Banks answered as follows $-35.67 \%$ of respondents strongly agreed, $19.33 \%$ of respondents agreed, 11.67 of respondents didn't hold any opinion, whereas $13.33 \%$ of respondents disagreed and $20 \%$ of respondents strongly disagreed.

Table 2: Frequency Distribution of respondents with respect to staff's behaviour in Private \& Nationalized Banks

\begin{tabular}{|c|c|c|c|c|c|}
\hline \multirow{2}{*}{$\begin{array}{c}\text { Private } \\
\text { Banks }\end{array}$} & \multicolumn{5}{|c|}{ The staff's behaviour was friendly and behaved in a courteous } \\
& $\begin{array}{c}\text { Strongly } \\
\text { Agree }\end{array}$ & Agree & $\begin{array}{c}\text { No } \\
\text { Opinion }\end{array}$ & Disagree & Strongly Disagree \\
\cline { 2 - 6 } & 80 & 120 & 30 & 40 & 30 \\
\hline Frequency & 26.67 & 40.00 & 10.00 & 13.33 & 10.00 \\
\hline Percentage & 26.00 &
\end{tabular}




\begin{tabular}{|c|c|c|c|c|c|}
\hline \multirow{2}{*}{$\begin{array}{c}\text { Nationalized } \\
\text { Banks }\end{array}$} & \multicolumn{5}{|c|}{ The staff's behaviour was friendly and behaved in a courteous } \\
manner during interactions? & $\begin{array}{c}\text { Strongly } \\
\text { Agree }\end{array}$ & Agree & $\begin{array}{c}\text { No } \\
\text { Opinion }\end{array}$ & Disagree & Strongly Disagree \\
\hline Frequency & 70 & 30 & 50 & 100 & 50 \\
\hline Percentage & 23.33 & 10.00 & 16.67 & 33.33 & 16.67 \\
\hline
\end{tabular}

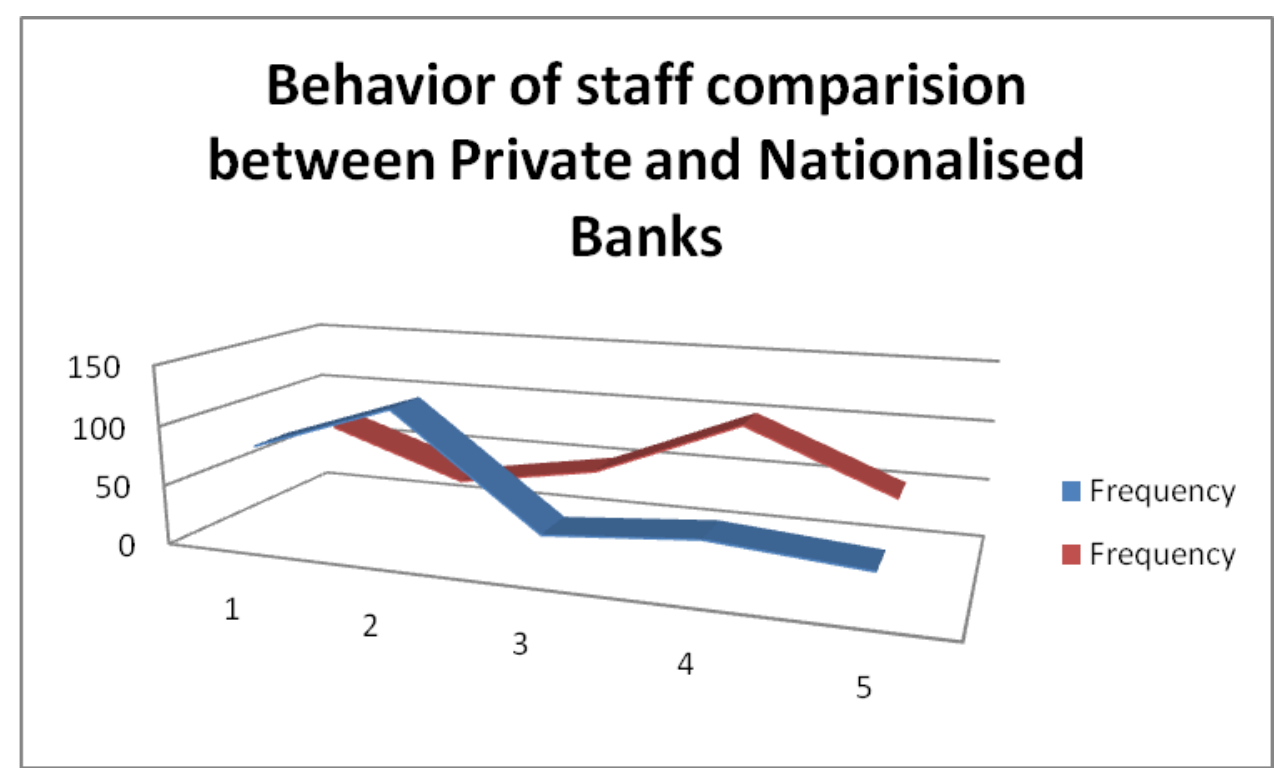

Figure 2: Comparison Line Graph for Frequency Distribution of respondents with respect to staff's behaviour in Private \& Nationalized Banks

It can be observed from the above graph and table that for the question posed to respondents regarding 'The staff's behaviour was friendly and behaved in a courteous manner during interactions?', The respondents of Private Banks answered as follows $-26.67 \%$ of respondents strongly agreed, $40 \%$ of respondents agreed, $10 \%$ of respondents didn't hold any opinion, whereas $13.33 \%$ of respondents disagreed and $10 \%$ of respondents strongly disagreed. The respondents of Nationalized Banks answered as follows $-23.33 \%$ of respondents strongly agreed, $10 \%$ of respondents agreed, 16.67 of respondents didn’t hold any opinion, whereas $33.33 \%$ of respondents disagreed and $16.67 \%$ of respondents strongly disagreed.

Table 3: Frequency Distribution of respondents with respect to professional appearance in Private \& Nationalized Banks

\begin{tabular}{|c|c|c|c|c|c|}
\hline \multirow{2}{*}{} & \multicolumn{5}{|c|}{ The staffs of the Bank are professional and have a pleasing and presentable } \\
appearance?
\end{tabular}

\begin{tabular}{|c|c|c|c|c|c|}
\hline \multirow{2}{*}{$\begin{array}{c}\text { Nationalized } \\
\text { Banks }\end{array}$} & \multicolumn{5}{|c|}{ The staffs of the Bank are professional and have a pleasing and presentable } \\
appearance?
\end{tabular}




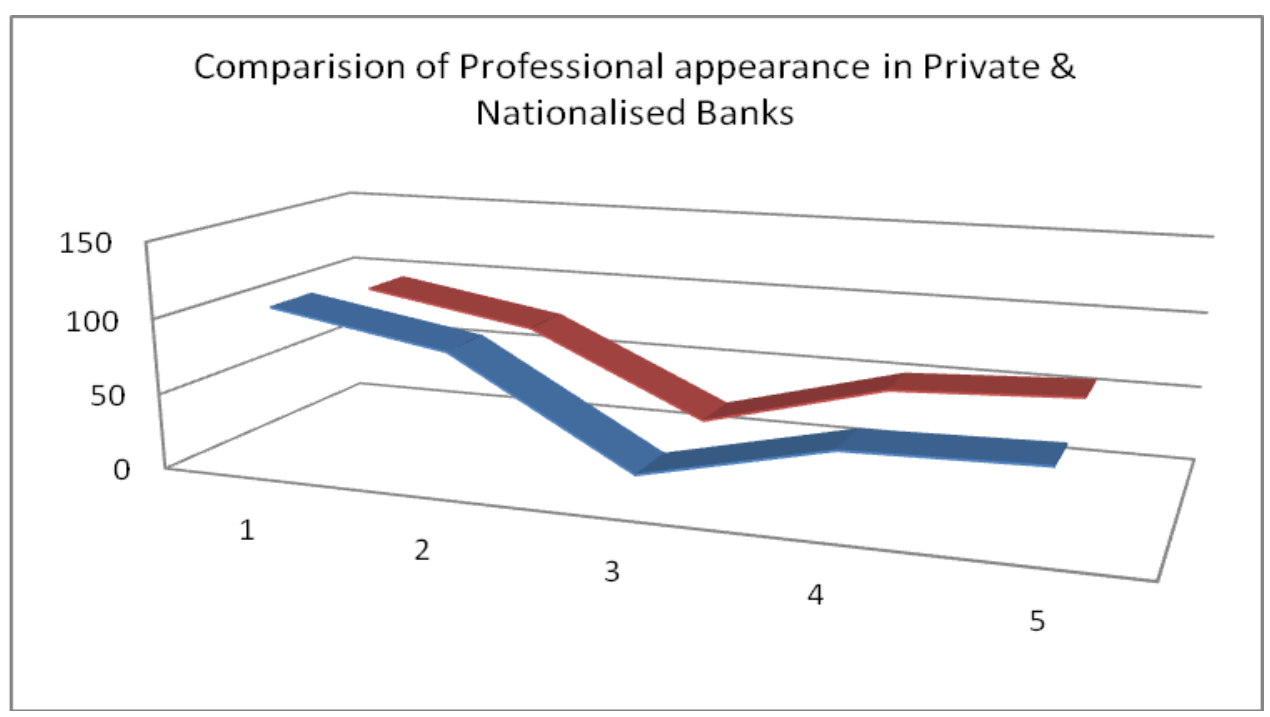

Figure 3: Comparison Line Graph for Frequency Distribution of respondents with respect to professional appearance in Private \& Nationalized Banks

It can be observed from the above graph and table that for the question posed to respondents regarding 'The staffs of the Bank are professional and have a pleasing and presentable appearance?', The respondents of Private Banks answered as follows - $35 \%$ of respondents strongly agreed, $28.33 \%$ of respondents agreed, $5.67 \%$ of respondents didn't hold any opinion, whereas $17.33 \%$ of respondents disagreed and $19.33 \%$ of respondents strongly disagreed. The respondents of Nationalized Banks answered as follows $-31.67 \%$ of respondents strongly agreed, $25 \%$ of respondents agreed, 6.67 of respondents didn't hold any opinion, whereas $33.33 \%$ of respondents disagreed and $16.67 \%$ of respondents strongly disagreed.

Table 4: Frequency Distribution of respondents with respect to willingness to listen in Private \& Nationalized Banks

\begin{tabular}{|c|c|c|c|c|c|}
\hline \multirow{2}{*}{$\begin{array}{c}\text { Private } \\
\text { Banks }\end{array}$} & \multicolumn{5}{|c|}{ The Bank staffs are willing to listen and respond to your needs on time? } \\
\cline { 2 - 6 } & Strongly Agree & Agree & No Opinion & Disagree & Strongly Disagree \\
\hline Frequency & 80 & 100 & 30 & 60 & 30 \\
\hline Percentage & 26.67 & 33.33 & 10.00 & 20.00 & 10.00 \\
\hline
\end{tabular}

\begin{tabular}{|c|c|c|c|c|c|}
\hline \multirow{2}{*}{$\begin{array}{c}\text { Nationalized } \\
\text { Banks }\end{array}$} & \multicolumn{5}{|c|}{ The Bank staffs are willing to listen and respond to your needs on time? } \\
\cline { 2 - 6 } & Strongly Agree & Agree & No Opinion & Disagree & Strongly Disagree \\
\hline Frequency & 50 & 70 & 25 & 85 & 70 \\
\hline Percentage & 16.67 & 23.33 & 8.33 & 28.33 & 23.33 \\
\hline
\end{tabular}

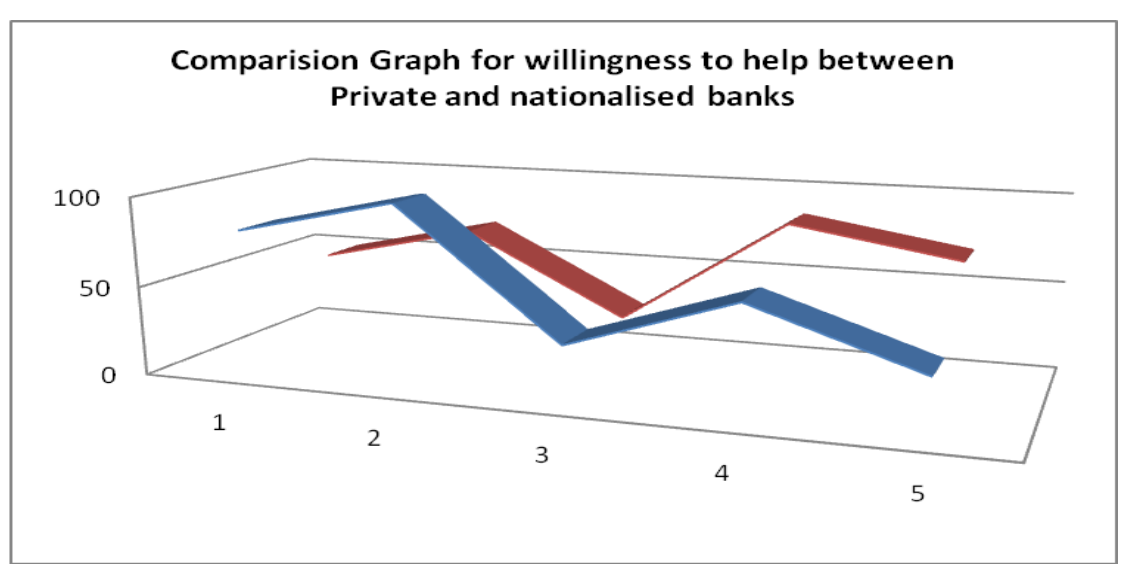

Figure 4: Comparison Line Graph for Frequency Distribution of respondents with respect to willingness to listen in Private \& Nationalized Banks 
It can be observed from the above graph and table that for the question posed to respondents regarding 'The Bank staffs are willing to listen and respond to your needs on time?', The respondents of Private Banks answered as follows - $26.67 \%$ of respondents strongly agreed, $33.33 \%$ of respondents agreed, $10 \%$ of respondents didn't hold any opinion, whereas $20 \%$ of respondents disagreed and $10 \%$ of respondents strongly disagreed. The respondents of Nationalized Banks answered as follows $-16.67 \%$ of respondents strongly agreed, $23.33 \%$ of respondents agreed, 8.33 of respondents didn't hold any opinion, whereas $28.33 \%$ of respondents disagreed and $23.33 \%$ of respondents strongly disagreed.

Table 5: Frequency Distribution of respondents with respect to Bank overall appearance in Private \& Nationalized Banks

\begin{tabular}{|c|c|c|c|c|c|}
\hline \multirow{2}{*}{$\begin{array}{c}\text { Private } \\
\text { Banks }\end{array}$} & \multicolumn{5}{|c|}{ The Bank overall appearance is neat and orderly? } \\
\cline { 2 - 6 } & Strongly Agree & Agree & No Opinion & Disagree & Strongly Disagree \\
\hline Frequency & 115 & 83 & 15 & 54 & 33 \\
\hline Percentage & 38.33 & 27.67 & 5.00 & 18.00 & 11.00 \\
\hline \multirow{2}{*}{$\begin{array}{c}\text { Nationalized } \\
\text { Banks }\end{array}$} & \multicolumn{5}{|c|}{ The Bank overall appearance is neat and orderly? } \\
\cline { 2 - 7 } & Strongly Agree & Agree & No Opinion & Disagree & Strongly Disagree \\
\hline Frequency & 105 & 63 & 20 & 64 & 48 \\
\hline Percentage & 35.00 & 21.00 & 6.67 & 21.33 & 16.00 \\
\hline
\end{tabular}

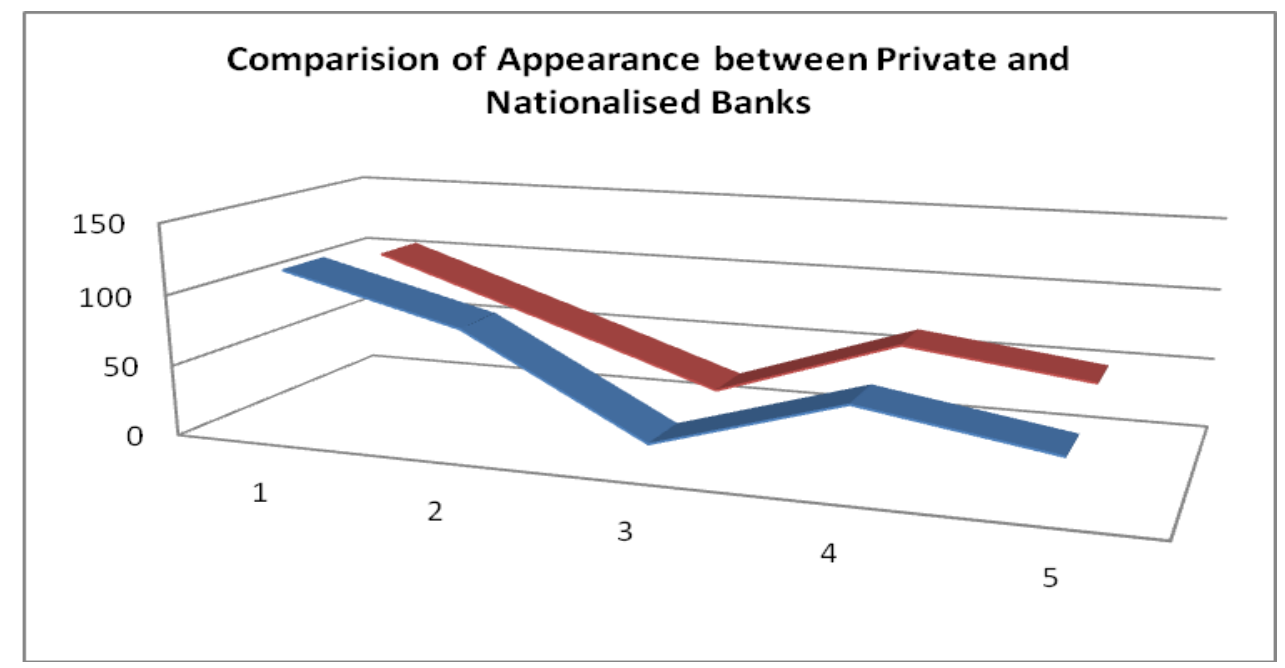

Figure 5: Comparison Line Graph for Frequency Distribution of respondents with respect to Bank overall appearance in Private \& Nationalized Banks

It can be observed from the above graph and table that for the question posed to respondents regarding 'The Bank overall appearance is neat and orderly?', The respondents of Private Banks answered as follows $38.33 \%$ of respondents strongly agreed, $27.67 \%$ of respondents agreed, $5 \%$ of respondents didn't hold any opinion, whereas $18 \%$ of respondents disagreed and $11 \%$ of respondents strongly disagreed. The respondents of Nationalized Banks answered as follows - 35\% of respondents strongly agreed, $21 \%$ of respondents agreed, $6.67 \%$ of respondents didn't hold any opinion, whereas $21.33 \%$ of respondents disagreed and $16 \%$ of respondents strongly disagreed.

\section{CONCLUSION:}

Banking sector today has a compelling demand for improvement, to survive the substantial competition in today's scenario. Public sector banks are always known for the trust, they have developed with the customers and for their existence in the society for a very long period of time. Hence, it is suggested that the public sector banks keep the trust factor and improve on the other aspects of service quality.

Also it is advisable that the public sector banks associate more with the technology and good infrastructure facilities to provide timely and efficient service to the customers. 
The customer needs grow with no limits, and it is very much evident from the various service offerings by the other banks day to day. Not just to rebel the competition with the private and the foreign banks, but also to retain the existing customers, it is very necessary that the public sector banks take a charge on this.

\section{REFERENCES:}

[1] Balakrishnan R Gayathri (2010), "Customer's Awareness About the Banking Services: A Study", Southern Economist, Vol. 49, No. 15, p. 2.

[2] Bharathe G Vijaya, Reddy P Mohan and Saritha P (2008), "Customer in Banking", Journal of Banking Finance.

[3] DCC Bank Report (2010).

[4] Fatima, S., EdwardGnanadhas, M. (2011). Impact of Service Quality In Commercial Banks On The Customersatisfaction:AnEmpiricalStudy. International Journal of Multidisciplinary Research Vol.1 Issue 6, October 2011, ISSN 2231 5780, 19-37.

[5] GhoshHazaraSandip and Kailash B L (2010), "Impact of Service Quality on Customer Satisfaction, Loyalty and Commitment in the Indian Banking Sector", Indian Journal of Marketing, Vol. 40, No. 5, p. 23.

[6] Heryanto. (2011). Effect of Service Quality On Customer Satisfaction With Bank Nagari ,Main Branch Padang. International journal of Business and Management Tomorrow Vol1 no.2, November 2011, ISSN:2249- 9962, 1-14.

[7] Jain S K and Gupta Garima (2004), "Measuring Service Quality: SERVQUAL vs. SERVPERF Scales", Vikalpa, Vol. 29, No. 2, pp. 25-37.

[8] Jain, Vibhor., Gupta, Sonia., Jain, Smrita. (2012). Customer Perception On Service Quality In Banking Sector:WithSpecialReference ToIndianPrivateBanks In Moradabad Region. IJRFM,Volume 2, Issue 2, February 2012, ISSN:2231-5985, 597-610.

[9] Jun, Minjoon., Cai, Shaohan. (2001). The Key Determinants Of Internet banking Service Quality: A Content Analysis. International Journal Of bank Marketing, July 2001, 276-291.

[10] K.A. Goyal \& Vijay Joshi, International Journal of Business Research and Management (IJBRM), Volume (3) : Issue (1) : 2012.

[11] Keerthe P and Vijayalaksmi R (2009), "A Comparative Study on the Perception Level of the Services Offered by Banks", Indian Journal of Marketing, Vol. XXXIX, No. 8, pp. 40-41. Kumar Ashok M and Rajesh R (2009), "Whether Today's Customer are Satisfied?", An Indian Journal of Marketing, Vol. XXXIX, No. 9, p. 46.

[12] Madhavaiah C (2005), "Service Quality in Telecommunications: A Case Study of BSNL, Kadapa", Unpublished M.Phil Dissertation Submitted to Annamalai University, Annamalainagar, Tamil Nadu.

[13] Malik, Muhammad Eshan., Naeem, Basharat., Arif, Zoune. (2011). How Do Service Quality Perceptions Contribute In satisfying Banking Customers?. Interdisciplinary Journal of Contemporary Research In Business Vol 3,No.8,December 2011, 646-653.

[14] Mehta, Parmita. Measuring Service Quality in Retail Banking Sector in Context of Gujarat. Ninth AIMS International Conference on Management,January 2012, 38-46. 